\title{
A new species of Zingiber (Zingiberaceae) east of Wallace's Line
}

\author{
M. Ardiyani ${ }^{1}$, M.F. Newman² \& A.D. Poulsen ${ }^{2}$ \\ ${ }^{1}$ Herbarium Bogoriense, Research Center for Biology, Indonesian Institute of Sciences, \\ Jl. Raya Bogor Km. 46, Cibinong 16912, Indonesia \\ marlina.ardiyani@lipi.go.id \\ ${ }^{2}$ Royal Botanic Garden Edinburgh, 20A Inverleith Row, \\ Edinburgh EH3 5LR, Scotland, UK
}

\begin{abstract}
Zingiber Mill. is distributed from India to the Pacific but only a few species are known from east of Wallace's Line, whereas the area to the west is rich in species. A recent collection from limestone at Bantimurung, South Sulawesi, Indonesia represents a new eastern species, Zingiber ultralimitale Ardiyani \& A.D.Poulsen, which is described, illustrated, and barcoded using three of the four barcoding loci ( $r b c \mathrm{~L}$, $t r n \mathrm{H}-p s b \mathrm{~A}$ and ITS). Placement of this species using morphological evidence is ambiguous but a combination of evidence from morphology, pollen anatomy and molecular analysis indicates that it belongs to Zingiber sect. Zingiber.
\end{abstract}

Keywords. Bantimurung, DNA barcode, Indonesia, limestone, Sulawesi, Wallacea

\section{Introduction}

Species of Zingiber Mill. occur from India in the west, through Malesia to the western Pacific, and those east of Wallace's Line are poorly known. There are about 180 species of Zingiber in the world (Zingiberaceae Resource Centre, 2017). Of the 45 species and six varieties of Zingiber occurring in Indonesia west of Wallace's Line (Ardiyani et al., unpublished), four cross Wallace's Line, all of them cultivated (Z. officinale Roscoe, Z. montanum (J.Koenig) A.Dietr., Z. odoriferum Blume, Z. zerumbet (L.) Sm.), indicating that their occurrence to the east may be anthropogenic.

Zingiber is currently classified into four sections based on the habit of the inflorescence (Baker, 1894; Schumann, 1904; see Table 1). Most Zingiber species occurring in Malesia belong to Zingiber sect. Zingiber.

Theilade et al. (1993) studied the pollen morphology of a range of species and found that it was not congruent with the division of the genus into sections. Their study showed that in Zingiber sect. Zingiber and Zingiber sect. Dymczewiczia (Horan.) Benth. \& Hook. the pollen grains are spherical with cerebroid sculpturing, whereas in Zingiber sect. Cryptanthium Horan. they are ellipsoid with spiro-striate sculpturing. For this reason, Theilade et al. suggested that Zingiber sect. Dymczewiczia should be included in Zingiber sect. Zingiber. 
The molecular study of Theerakulpisut et al. (2012) supports the classification of Zingiber into four sections although Zingiber sect. Zingiber and Zingiber sect. Dymczewiczia are only weakly supported. This weak support does not, therefore, necessarily refute Theilade's conclusion that Zingiber sect. Dymczewiczia should be included in Zingiber sect. Zingiber. These two sections are more closely related to each other than to Zingiber sect. Cryptanthium and Zingiber sect. Pleuranthesis Benth. \& Hook. (Theerakulpisut et al., 2012).

Plants of an unidentified Zingiber were collected from limestone at Bantimurung, South Sulawesi in 2009. When they were first encountered, several individuals could be seen from the road but they were not easy to reach. At first the sterile plants were thought to be a species of Globba L. different from the only other species known to occur east of Wallace's Line, G. marantina L. As this would be a biogeographically exciting discovery, we decided to try to collect sterile plants for cultivation. Despite some difficulty because the roots were deeply anchored in cracks in the limestone, we managed to collect 10 plantlets that were exported to Java, half of which were deposited in Bogor Botanic Gardens and the other half in the Royal Botanic Garden Edinburgh (accession numbers 20092015-20092019). Some of the plants flowered in Edinburgh, enabling us to conclude that it is an undescribed species which we here name Zingiber ultralimitale, and to make a full description including floral details and pollen morphology. In addition to describing this species formally, we investigate the sectional placement of this geographically unusual find using palynological data and molecular systematic analyses.

Table 1. Sections of Zingiber with their characteristics and geographical distribution (Baker 1894; Schumann 1904; Theerakulpisut et al. 2012).

\begin{tabular}{llll}
\hline Section & Geography & Inflorescence & Pollen morphology \\
\hline Zingiber & $\begin{array}{l}\text { India, China, Indo- } \\
\text { China, Thailand, } \\
\text { Peninsular Malaysia, } \\
\text { Sumatra, Borneo, Java, } \\
\text { Cultivated }\end{array}$ & $\begin{array}{l}\text { Borne on radical, erect } \\
\text { peduncle or borne } \\
\text { apically on a leafy stem }\end{array}$ & $\begin{array}{l}\text { Spherical with cerebroid } \\
\text { exine sculpturing }\end{array}$ \\
& $\begin{array}{l}\text { India, Thailand, China, } \\
\text { Indo-China }\end{array}$ & $\begin{array}{l}\text { Borne on a radical, } \\
\text { procumbent peduncle }\end{array}$ & $\begin{array}{l}\text { Ellipsoidal with spiro-striate } \\
\text { sculpturing }\end{array}$ \\
& $\begin{array}{l}\text { India, China, Indo- } \\
\text { China, Thailand, Java, } \\
\text { Papua New Guinea }\end{array}$ & $\begin{array}{l}\text { Borne apically on a } \\
\text { leafy stem }\end{array}$ & $\begin{array}{l}\text { Spherical with cerebroid } \\
\text { exine sculpturing }\end{array}$ \\
& $\begin{array}{l}\text { China (Yunnan), } \\
\text { Vietnam }\end{array}$ & $\begin{array}{l}\text { Arising from the side of } \\
\text { the leafy stem }\end{array}$ & $\begin{array}{l}\text { Spherical with cerebroid } \\
\text { exine sculpturing }\end{array}$ \\
\hline
\end{tabular}




\section{Material and methods}

Detailed studies of the morphology were made using living collections grown in the greenhouse of the Royal Botanic Garden Edinburgh. Measurements were made using a ruler and a calibrated eye piece under a dissecting microscope.

For the DNA barcoding, three barcoding regions were successfully sequenced, namely $r b c \mathrm{~L}$, trnH-psbA and the nuclear Internal Transcribed Spacer (ITS). The fourth barcoding region, matK could not be sequenced. Extraction, amplification and sequencing followed Kress et al. (2002) and Kress \& Erickson (2007). The material sequenced was from Poulsen et al. 2767. GenBank accession numbers for the three barcoding regions are summarised in Table 2. A phylogenetic analysis based on ITS sequences was performed using additional sequences from NCBI GenBank after BLAST was done. GenBank has very few records of $r b c \mathrm{~L}$ and $t r n \mathrm{H}-p s b \mathrm{~A}$ so it was not possible to run an analysis using these regions to address the affiliation of Zingiber ultralimitale. Kaempferia parviflora Wall. ex Baker and K. elegans (Wall.) Baker were chosen as the outgroup following Theerakulpisut et al. (2012) (Table 3). Sequence alignment and Maximum Likelihood analysis were conducted using MEGA version 6 (Tamura et al., 2013).

Table 2. Voucher information and Genbank accession numbers.

\begin{tabular}{clll}
\hline \multicolumn{1}{c}{ Species } & Gene region & $\begin{array}{l}\text { Genbank accession } \\
\text { number }\end{array}$ & $\begin{array}{l}\text { Material } \\
\text { (Herbarium location) }\end{array}$ \\
\hline Zingiber ultralimitale & $r b c \mathrm{~L}$ & KU891637 & $\begin{array}{l}\text { Poulsen et al. 2767 } \\
\text { (BO, E) } \\
\end{array}$ \\
& IrnH-psbA & KU891638 & \\
\hline
\end{tabular}

For the palynological study, material was collected from a living plant growing at the Royal Botanic Garden Edinburgh (acc. no 20092015 A) and fixed in FAA for at least 24 hours. Mature but unopened flowers were selected. For SEM, anthers were dissected from the flowers, put into tiny chambers and dehydrated for 45 minutes in $50 \%, 70 \%, 95 \%$, and $100 \%$ ethanol, ten minutes in acetone (two changes of five minutes each). Critical point drying was carried out in an Emitech K850 dryer and samples were sputter-coated with platinum and examined using a Zeiss Supra 55VP SEM.

\section{Results and discussion}

Most of the Zingiber species of western Malesia have tightly imbricate bracts, long or very short peduncles, and lateral staminodes joined to the labellum, although Zingiber 
Table 3. Species of Zingiber and outgroups obtained from NCBI GenBank.

\begin{tabular}{|c|c|c|c|}
\hline No & Species & Distribution/Section & $\begin{array}{l}\text { GenBank Acc. } \\
\text { No. (ITS) }\end{array}$ \\
\hline & Zingiber (ingroup) & & \\
\hline 1 & Z. barbatum Wall. & Thailand/Zingiber & DQ064578 \\
\hline 2 & Z. bradleyanum Craib & Thailand/Cryptanthium & DQ064579 \\
\hline 3 & Z. capitatum Roxb. & India, Himalaya/Zingiber & KM983532 \\
\hline 4 & Z. capitatum & India, Himalaya/Zingiber & KM983536 \\
\hline 5 & Z. citriodorum Theilade \& Mood & Thailand/Zingiber & DQ064591 \\
\hline 6 & Z. coloratum N.E.Br. & Borneo/Zingiber & AF414498 \\
\hline 7 & Z. corallinum Hance & Thailand, China/Zingiber & AF254460 \\
\hline 8 & Z. corallinum & Thailand, China/Zingiber & DQ064587 \\
\hline 9 & $\begin{array}{l}\text { Z. ellipticum (S.Q.Tong \& Y.M.Xia) } \\
\text { Q.G.Wu \& T.L.Wu }\end{array}$ & Yunnan-China/Pleuranthesis & AF478799 \\
\hline 10 & Z. fragile S.Q.Tong & Thailand/Cryptanthium & DQ064581 \\
\hline 11 & Z. gramineum Noronha ex Blume & $\begin{array}{l}\text { Indochina, Java, } \\
\text { Sumatra/Zingiber }\end{array}$ & DQ064577 \\
\hline 12 & Z. gramineum & $\begin{array}{l}\text { Indochina, Java, } \\
\text { Sumatra/Zingiber }\end{array}$ & AF478800 \\
\hline 13 & Z. isanense Triboun \& K.Larsen & Thailand/Zingiber & DQ064586 \\
\hline 14 & Z. junceum Gagnep. & Thailand/Zingiber & DQ064588 \\
\hline 15 & Z. junceum & Thailand/Zingiber & AY424774 \\
\hline 16 & Z. longipedunculatum Ridl. & Borneo/Zingiber & АВ097254 \\
\hline 17 & $\begin{array}{l}\text { Z. montanum (J.Koenig) Link ex } \\
\text { A.Dietr. }\end{array}$ & Cultivated/Zingiber & KJ872221 \\
\hline 18 & Z. montanum & Cultivated/Zingiber & DQ064585 \\
\hline 19 & $\begin{array}{l}\text { Z. neesanum (J.Graham) } \\
\text { Ramamoorthy }\end{array}$ & India, Indochina/Zingiber & KJ872228 \\
\hline 20 & Z. neesanum & India, Indochina/Zingiber & KJ872226 \\
\hline 21 & $\begin{array}{l}\text { Z. neotruncatum T.L.Wu, K.Larsen \& } \\
\text { Turland }\end{array}$ & India, China/Zingiber & DQ064589 \\
\hline 22 & Z. newmanii Theilade \& Mood & Thailand/Zingiber & DQ064575 \\
\hline 23 & Z. odoriferum Blume & Cultivated/Zingiber & KF304561 \\
\hline 24 & Z. odoriferum & Cultivated/Zingiber & KF304562 \\
\hline 25 & Z. officinale Roscoe & Cultivated/Zingiber & DQ064590 \\
\hline 26 & Z. orbiculatum S.Q.Tong & Thailand/Cryptanthium & DQ064573 \\
\hline 27 & Z. ottensii Valeton & Cultivated/Zingiber & DQ064582 \\
\hline 28 & Z. ottensii & Cultivated/Zingiber & AJ388298 \\
\hline 29 & Z. parishii Hook.f. & Thailand/Zingiber & KF304567 \\
\hline 30 & Z. parishii & Thailand/Zingiber & DQ064576 \\
\hline 31 & Z. pellitum Gagnep. & Thailand/Dymczewiczia & DQ064574 \\
\hline 32 & $\begin{array}{l}\text { Z. purpureum Roscoe (syn. of } Z \text {. } \\
\text { montanum) }\end{array}$ & Cultivated/Zingiber & HM236153 \\
\hline 33 & Z. rubens Roxb. & Thailand/Cryptanthium & DQ064580 \\
\hline 34 & Z. spectabile Griff. & $\begin{array}{l}\text { Sumatra, Malay } \\
\text { Peninsula/Zingiber }\end{array}$ & AF414499 \\
\hline 35 & Z. sulphureum Burkill ex Theilade & $\begin{array}{l}\text { Sumatra, Malay } \\
\text { Peninsula/Zingiber }\end{array}$ & AF478801 \\
\hline 36 & Z. wrayi Prain ex Ridl. & $\begin{array}{l}\text { Sumatra, Malay Peninsula, } \\
\text { Thailand/Zingiber }\end{array}$ & AF478802 \\
\hline 37 & Z. wrayii & $\begin{array}{l}\text { Sumatra, Malay Peninsula, } \\
\text { Thailand/Zingiber }\end{array}$ & DQ064583 \\
\hline
\end{tabular}


Table 3. Continued.

\begin{tabular}{|c|c|c|c|}
\hline No & Species & Distribution/Section & $\begin{array}{l}\text { GenBank Acc. } \\
\text { No. (ITS) }\end{array}$ \\
\hline 38 & Z. zerumbet (L.) Roscoe ex Sm. & Cultivated/Zingiber & KC582863 \\
\hline 39 & Z. zerumbet & Cultivated/Zingiber & DQ064584 \\
\hline 40 & $\begin{array}{l}\text { Z. ultralimitale Ardiyani \& } \\
\text { A.D.Poulsen }\end{array}$ & Sulawesi/Zingiber & KU891639 \\
\hline 41 & $\begin{array}{l}\text { Z. ultralimitale } \\
\text { Kaempferia (outgroup) }\end{array}$ & Sulawesi/Zingiber & KU891639 \\
\hline 42 & Kaempferia elegans (Wall.) Baker & China, Indochina, Malesia & AY424764 \\
\hline 43 & K. parviflora Wall. ex Baker & India, Indochina & DQ064592 \\
\hline
\end{tabular}

engganoense Ardiyani from Enggano Island, Sumatra (Ardiyani, 2015), has a long peduncle with tightly imbricate bracts and lateral staminodes free from the labellum. Zingiber ultralimitale, by contrast, has loosely imbricate bracts and relatively large yellow lateral staminodes which are free from the labellum. Loosely imbricate bracts are found in Zingiber sect. Cryptanthium west of Wallace's Line in Asia. Some species of Zingiber sect. Cryptanthium which resemble Z. ultralimitale are Z. nanlingensis Lin Chen et al. from China with the same arrangement of inflorescence and yellow flowers but staminodes not free from the labellum; Zingiber liangshanense Z.Y.Zhu, also from China, with free staminodes but a purple labellum; and Z. chrysanthum Roscoe from Nepal with bright red corolla lobes. Zingiber ultralimitale is morphologically distinct from the other species in Zingiber sect. Zingiber by having the bract arrangement of Zingiber sect. Cryptanthium.

A phylogenetic analysis of sequence data from the Internal Transcribed Spacer (ITS) results in an unresolved backbone in the phylogenetic tree of Zingiber. Zingiber ultralimitale is well supported as belonging to Zingiber sect. Zingiber (Fig. 1).

The pollen grains of Zingiber ultralimitale are spherical with cerebroid sculpturing (Fig. 2) which, according to Theilade et al. (1993), is characteristic of Zingiber sect. Zingiber. Furthermore, the molecular results also place Zingiber ultralimitale in Zingiber sect. Zingiber (Fig. 1). Taking all the evidence together, therefore, we place the species in Zingiber sect. Zingiber.

\section{Taxonomy}

Zingiber ultralimitale Ardiyani \& A.D.Poulsen, sp. nov.

This species is distinct from all others by the following combination of characters: narrow long loose green bracts, bright yellow flowers, and large free yellow lateral staminodes.-TYPE: Indonesia, originally collected from South Sulawesi Province, Bantimurung NP, along Jalan Poros Maros-Soppeng, and cultivated as RBGE 20091017*A, flowering material vouchered on 12 June 2013 as Newman, M.F. 2552 (holotype BO; isotype E). (Fig. 2, 3) 


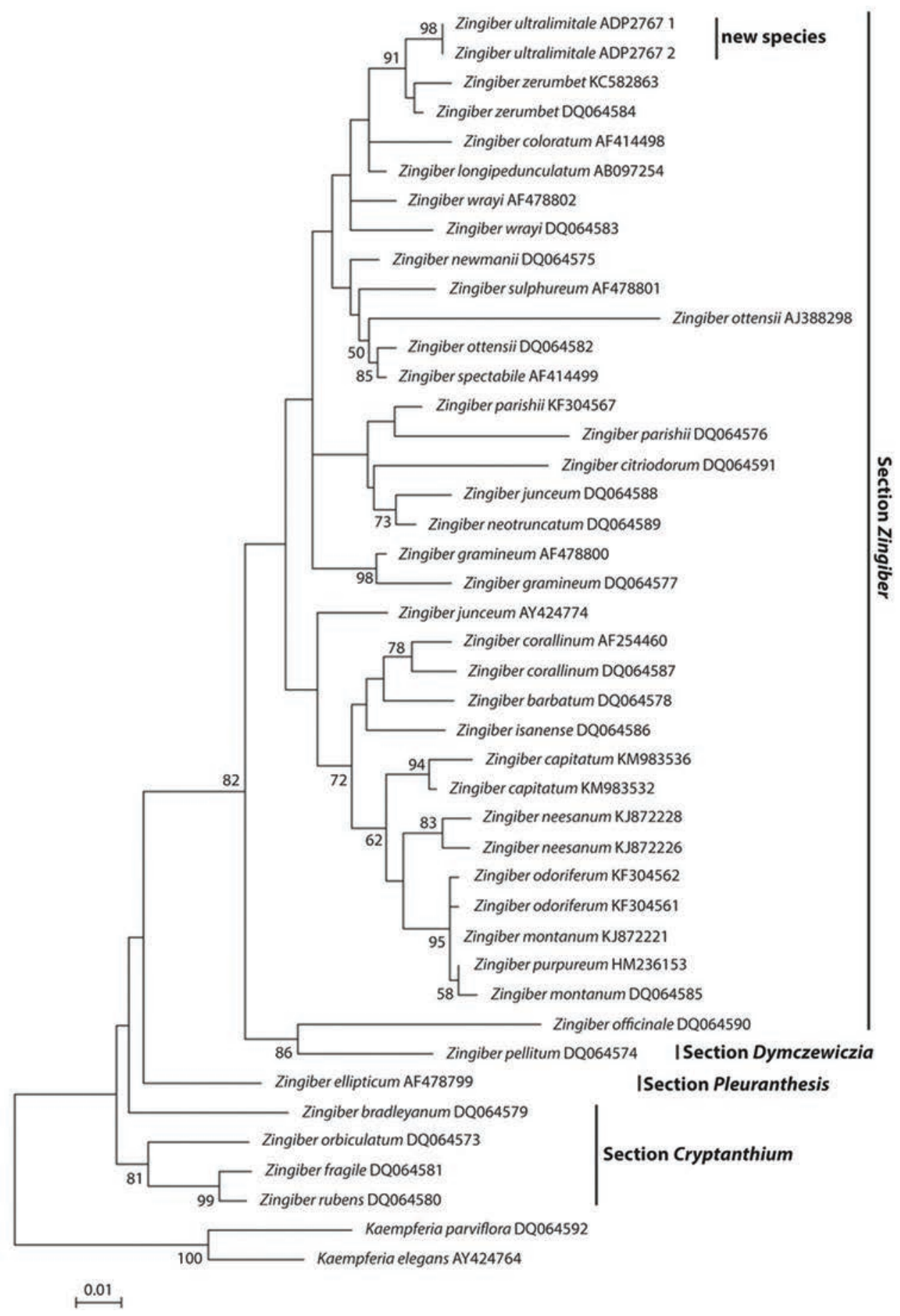

Fig. 1. Phylogenetic tree of Zingiber based on Maximum Likelihood analysis using the Internal Transcribed Spacers data (ITS). Bootstrap values (based on 1000 replicates) are presented above the branches. Only Bootstrap values higher than $50 \%$ are shown. 
Lithophytic herb. Rhizome branching profusely, 5-8 mm across, brown externally, yellowish internally, tasting like Zingiber officinale but very bitter; roots with irregular ellipsoid tubers to $2.5 \times 1.5 \mathrm{~cm}$, white in cross-section, tasting like potato. Leafy shoots in a loose clump of up to five pseudostems, 2-4 cm apart, to 40-75 cm tall, with 9-12(20) leaves. Base of leafy shoot to $9 \mathrm{~mm}$ diam., white to yellowish brown. Sheaths light green to mid-green, \pm finely hairy especially near margin and apex. Ligule to $8 \mathrm{~mm}$ long, membranous, emarginate at least for half its length, with scattered, appressed hairs, pale green. Petiole 2-9 mm long, channelled above, appressed villose abaxially, especially in lower half. Lamina ovate to narrowly ovate, 9-18 × 3.5-5.5 cm, slightly plicate, yellowish green and glabrous above, pale green and sparsely appressed villose beneath especially near midrib, base rounded when fresh, cuneate to truncate when dried, apex long acuminate. Inflorescence erect, to $16 \mathrm{~cm}$ long, arising close to the base of leafy shoot, with 9-12 flowers, one flower open at a time in late morning. Peduncle 3-6 cm long with 4 peduncular bracts, upper one to $4.5 \mathrm{~cm}$ long, being the longest, with scattered fine hairs. Spike to $10.5 \mathrm{~cm}$ long. Bracts laxly arranged at an angle to the rachis, c. $5 \mathrm{~mm}$ apart exposing the mid-green rachis, each subtending a single flower, lowermost bract c. $4.5 \times 1.7 \mathrm{~cm}$, translucent pale green, slightly darker towards apex, with visible cross-veins and hyaline margins, apex of lower bracts acuminate,

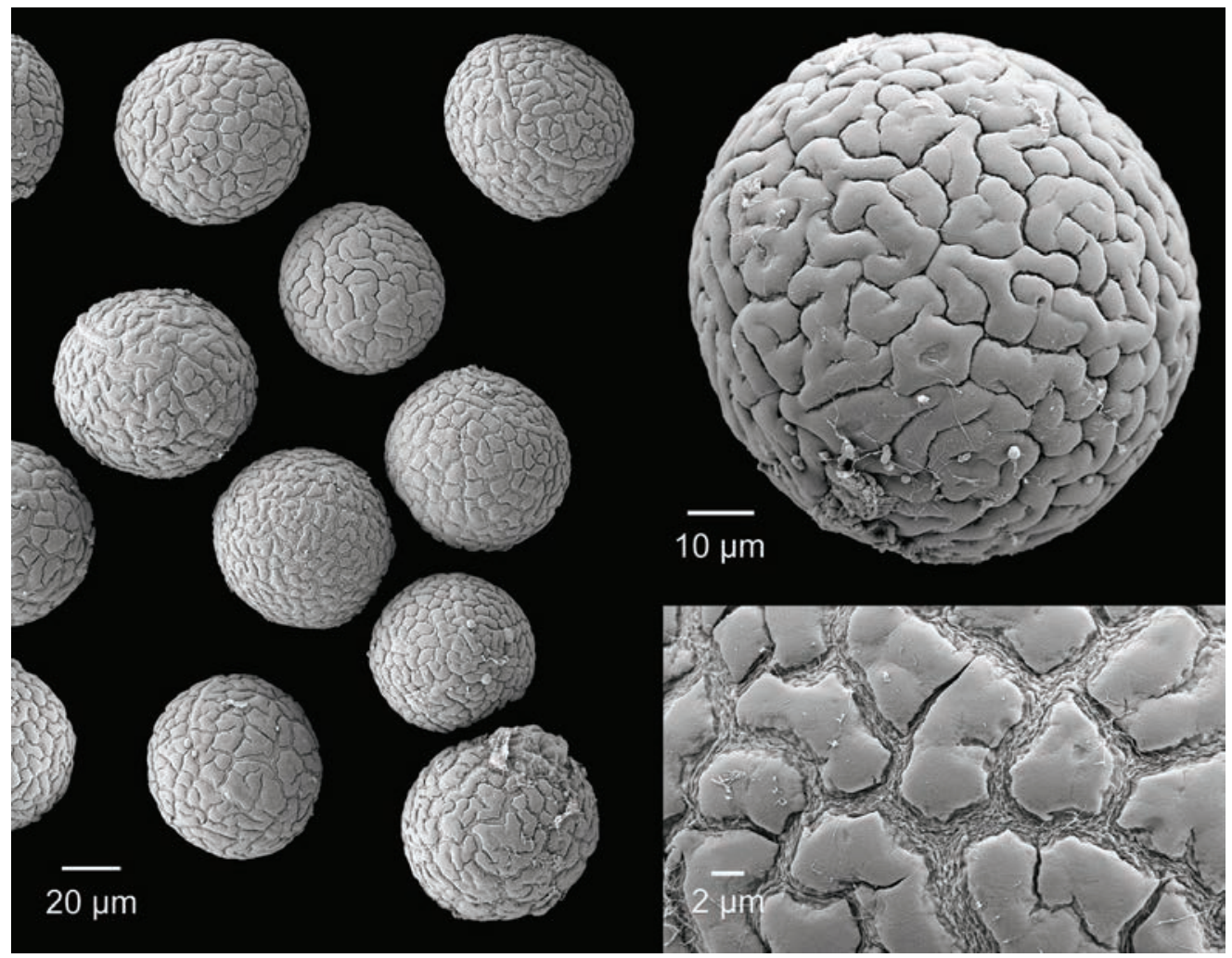

Fig. 2. Pollen of Zingiber ultralimitale (acc. no 20092015 A). SEM made by Zou Pu. 


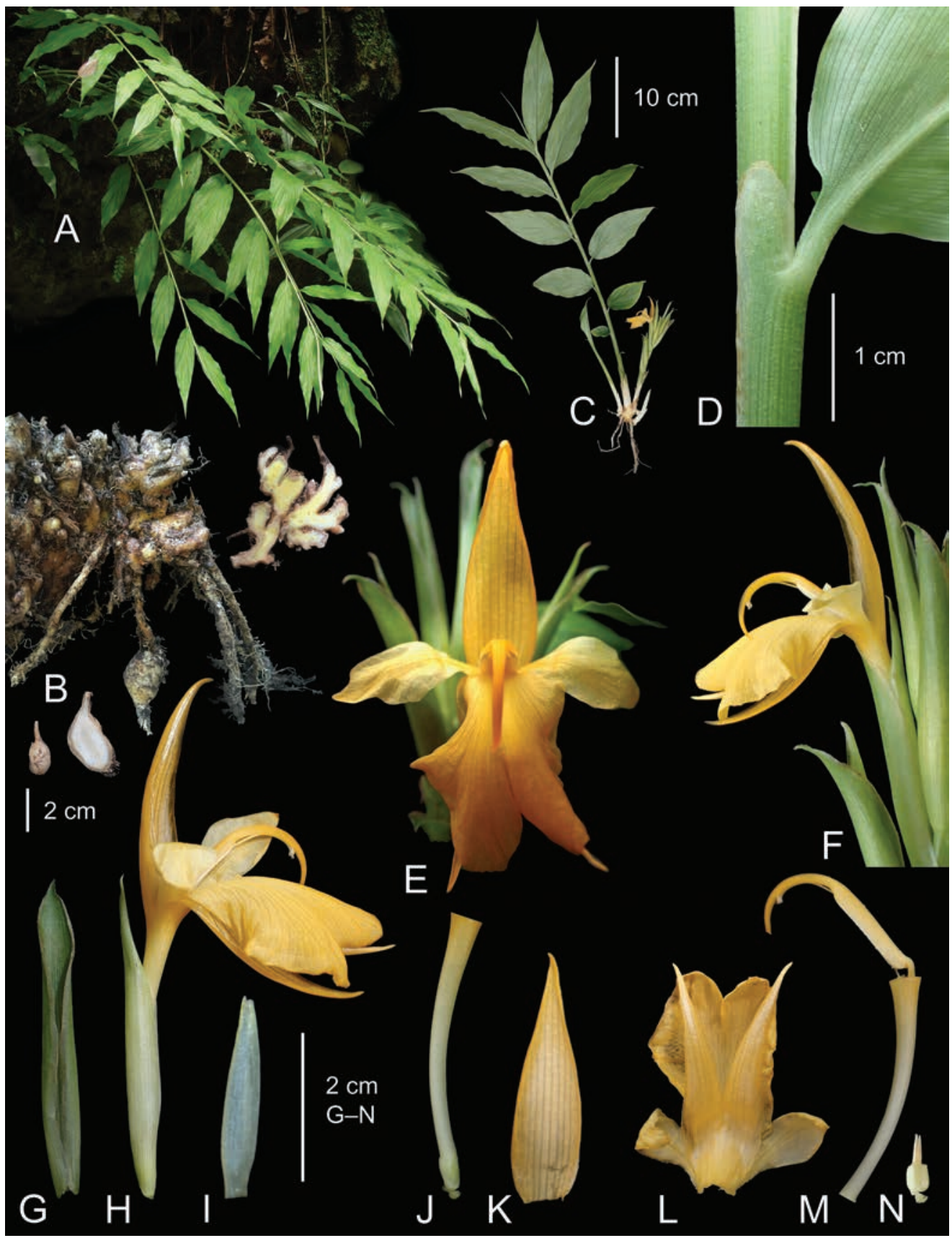

Fig. 3. Zingiber ultralimitale Ardiyani \& A.D.Poulsen. A. Habit on limestone boulders at Bantimurung. B. Rhizome, including roots with tubers. C. Leafy shoot and inflorescence. D. Sheath, ligule, petiole and base of lamina. E. Spike with single flower, front view. F. Spike with single flower, lateral view. G. Bract. H. Bracteole and flower. I. Calyx. J. Ovary and corolla tube. K. Dorsal corolla lobe, ventral view. L. Labellum and lateral corolla lobes, ventral view. M. Corolla tube, stamen and stigma. N. Ovary and epigynous glands. A from Poulsen et al. 2767; B from Poulsen \& Yeats 2989; C-N from Poulsen \& Yeats 2984. (Photos: A.D. Poulsen) 
upper bracts with apex recurved, subulate appendages 6-8 $\mathrm{mm}$ long (reminiscent of a reduced lamina), finely ciliate especially near margin and apex, glabrous inside. Bracteoles \pm as long as bracts, longer than calyx, to $4.6 \times 1.3 \mathrm{~cm}$ (when flattened), split to base, margins supervolute, translucent cream at base becoming green towards apex, with scattered hairs near margin and along veins, glabrous inside. Calyx c. $2.6 \mathrm{~cm}$ long, tubular with one incision in upper half, membranous, translucent cream, minutely three-toothed at the apex, pubescent at apex. Corolla tube c. $3.5 \mathrm{~cm}$ long, white at base, becoming pale yellow apically; dorsal corolla lobe narrowly ovate, slightly hollow, c. $3.4 \times 1.2 \mathrm{~cm}$, pale orange-yellow; lateral corolla lobes narrowly ovate, c. $2.5 \times 0.7$ cm, adnate c. $3 \mathrm{~mm}$ to base of labellum, pale orange-yellow. Labellum obovate, c. $3.5 \times 3-3.5 \mathrm{~cm}$, central lobe c. $3.5 \times 2-2.5 \mathrm{~cm}$, bifid, incision c. $8 \mathrm{~mm}$, the two halves slightly divergent and recurved, glabrous throughout, pale orange-yellow. Lateral staminodes (side lobes) petaloid, c. $2 \times 0.8 \mathrm{~cm}$, paler than labellum, and free from it. Stamen c. $3 \mathrm{~cm}$ long, filament distinct, c. $0.3 \mathrm{~cm}$ long, pale orange-yellow, anther c. $1.5 \mathrm{~cm}$, crest 1.3-1.6 cm long (when stretched), wrapped around style, incurved, pale orange. Anther thecae open along their entire length, \pm white. Style pale yellow. Stigma tubular with a downwards-facing, ciliate ostiole which holds a droplet, held by anther crest; epigynous glands 2, subulate, $4 \mathrm{~mm}$ long, pale yellow. Ovary c. $4 \times 3$ $\mathrm{mm}$, trilocular, sometimes incompletely so, with axile placentation, ovules c. 25-30, pale yellow-green. Fruit not seen.

Distribution. Only known from the type locality in South Sulawesi.

Etymology. The specific epithet ultralimitale means 'on the other side of the border', referring to the occurrence of this species east of Wallace's Line.

Ecology and habitat. Limestone cliffs and boulders in forest, lowlands at c. $300 \mathrm{~m}$. During the first year of cultivation in Edinburgh, it was discovered that the species has a dormancy period during which it survives entirely underground.

Phenology. Flowering in May-June in cultivation. Our field assistant, Firdaus, checked the populations at the type locality in June 2016 and found no leafy shoots. From this we infer that the onset of the dry season had already resulted in the plant becoming dormant.

Conservation status. Vulnerable VU B1ab(iii) (IUCN, 2001). Abundant at one locality along the road inside a national park but the extent of occurrence is estimated as $<20,000 \mathrm{~km}^{2}$. It is known from $<10$ locations and there is a decline in extent and quality of the limestone habitats in Sulawesi.

Additional specimens examined. INDONESIA: South Sulawesi: Bantimurung National Park, along Jalan Poros Maros-Soppeng, 5²'32.4"S 11944'9.4"E, 340 m, 23 January 2009, A.D. Poulsen et al. 2767 (BO, E); Bantimurung National Park, along Jalan Poros Maros-Soppeng, $5^{\circ} 2^{\prime} 32.4^{\prime \prime S} 119^{\circ} 44^{\prime} 9.4^{\prime \prime} \mathrm{E}, 340$ m, 23 January 2009, living collection of Poulsen, A.D., Marlina 
Ardiyani \& Firdaus 2767 cultivated as RBGE 20091015*A, vouchered 12 June 2013 as Newman, M.F. 2551, flowering (BO, E); ibidem, cultivated as $20091017^{*}$ A, vouchered 28 May 2015 as Poulsen \& Yeats 2984, flowering (E); ibidem, cultivated as $20091017^{*}$ A, vouchered 5 Feb 2016 as Poulsen \& Yeats 2989, dormant (E); ibidem, cultivated as $20091017^{*}$ A, vouchered 9 June 2016 as Yeats 16, flowering (E, SING); ibidem, cultivated as 20091019*A, vouchered 21 June 2016 as Yeats 17, flowering (E, CEB).

Notes. The rhizome branches and forms large clumps in cultivation, which explains why it was almost impossible to remove it from the cracks in the limestone boulders of its natural habitat. The leafy shoots collected in the field were much longer than those of cultivated plants (75 vs. $40 \mathrm{~cm}$ ) and had up to 20 leaves per shoot (vs. up to 12) which were narrower. In 2015, only one of the plants in the glasshouses produced an inflorescence, which contained a total of 12 flowers usually opening late morning. Only one flower opened per day but sometimes there would be a day without flowers in between.

ACKNOWLEDGEMENTS. The Davis Expedition Fund, Augustinus, and Blaxall Valentine Awards sponsored the expedition in Indonesia in 2009 during which the plant was discovered. The Sibbald Trust funded A.D. Poulsen as a Davis Research Fellow. The State Ministry of Research and Technology (RISTEK) issued the necessary permit. We are indebted to Helen Yeats, RBGE for keeping the plants alive, thereby enabling us to study the flowers and describe the species, and for making additional collections for herbaria. The Royal Botanic Garden Edinburgh (RBGE) is supported by the Scottish Government's Rural and Environmental Science and Analytical Services Division. We thank J.F. Veldkamp and Philip Oswald for help in Latinising the epithet, Zou Pu for letting us include her pollen photos, Firdaus for travelling to the type locality to check the phenology, and Ida Theilade, Pramote Triboun, Bai Lin, John Mood and Jana Leong-Škorničková for useful discussions. We also thank Susila and Hani Kharismantari for helping us in the Molecular Lab, Herbarium Bogoriense, Research Center for Biology, LIPI. Last but not least, the first author would like to thank the Sibbald Trust of the Royal Botanic Garden Edinburgh which allowed her to examine the herbarium specimens of Zingiber at E and K after the 10th Flora Malesiana Symposium.

\section{References}

Ardiyani, M. (2015). A new species of Zingiber (Zingiberaceae) from Enggano Island, Indonesia. Reinwardtia 14(2): 307-310.

Baker, J.G. (1894). Scitamineae. In: Hooker, J.D. (ed.) Flora of British India, vol. 6, pp. 198264. London: L Reeve \& Co.

IUCN (2001). IUCN Red List Categories and Criteria: Version 3.1. Gland, Switzerland and Cambridge, UK: IUCN.

Kress, W.J. \& Erickson, D.L. (2007). A two-locus global DNA barcode for land plants: The coding $r b c \mathrm{~L}$ gene complements the non-coding trnH-psbA spacer region. PLoS ONE 2: e508.

Kress, W.J., Prince, L.M. \& Williams, K.J. (2002). The phylogeny and a new classification of the gingers (Zingiberaceae): evidence from molecular data. Am. J. Bot. 89: 1682-1696. 
Schumann, K. (1904). Zingiberaceae. In: Engler, H.G.A. (ed.) Das Pflanzenreich, IV(46), fas. 20, pp. 1-458. Leipzig: W. Engelmann.

Tamura, K., Stecher, G., Peterson, D., Filipski, A. \& Kumar, S. (2013). MEGA6: Molecular Evolutionary Genetics Analysis version 6.0. Molec. Biol. Evol. 30: 2725-2729.

Theerakulpisut, P., Triboun, P., Mahakham, W., Maensiri, D., Khampila, J. \& Chantaranothai, P. (2012). Phylogeny of the genus Zingiber (Zingiberaceae) based on nuclear ITS sequence data. Kew Bull. 67: 389-395.

Theilade, I., Mærsk-Møller, M.L., Theilade, J. \& Larsen, K. (1993). Pollen morphology and structure of Zingiber (Zingiberaceae). Grana 32: 338-342.

Zingiberaceae Resource Centre (2017). Royal Botanic Garden Edinburgh. http://padme.rbge. org.uk/ZRC/welcome. Accessed 3 Jul. 2017. 
